\title{
Masculism in Communication Is Seen by Women as a Key Success Factor to be Accepted as Equals in the Political Sphere
}

\author{
Miranda Cili \\ European University of Tirana, Tirana, Albania
}

\begin{abstract}
In democratic countries, representing all the social categories has a first-hand importance. Not only Albanian political reality, but also the political environment, is generally defined by a strong masculine presence, considering it as a profession for men. On the other hand, it can be seen that even though Albanian politics is "violent”, women are still approaching in it, who are only considered as "beautiful beings", because the national destiny is on "their hands". The political situation in terms of communication in the country is almost always in a kind of tension, but certainly in parliamentary and local elections. Instead of lowering the tension level of communicating, they were wilder. Insults, which make people get embarrassed of hearing them, but not the one who expresses those words, have been present even though not expressed publicly. Nervous glance and spiteful minds have been present not only for respecting others and those who think differently, but also to neglect the other. It has been seen that beyond the soft voice they pronounce, the words expressed have been impolite.
\end{abstract}

Keywords: gender equality, quotes, political communication, masculism, political language, women in politics

\section{Introduction}

Building a democratic regime after 1990 has put the Albanian citizens to face the challenge of building a liberal democracy with functioning institutions, which means that in addition to building structures, formal legal citizens should be active participants in the process. (Danaj, 2008)

Not only Albanian political reality, but also the political environment, is generally defined by a strong masculine presence, considering it as a profession for man. Referring Albanian reality, representation of citizen groups in the Albanian parliament is very low. Feminism is an ideology that was born and later tries to analyze the social position of women, explaining their important role in the story and providing the basis for reform and progress of women in all areas of society (Harrison \& Boyd, 2003). However, this does not mean that "feminism" has emerged and exists as an ideology or practice in any political party and even less on political parties.

The elections of 2009 in Albania as well as local ones in 2011 were seen as a good opportunity to increase the number of women representation in politics in improving the representation in parliament. However, it did not gain the objectives set by law for gender equality.

The decision of defining the numbers of women in parliament found a wide public consensus although many doubts were raised in the process of selection of women politicians and indeed it had such a policy in Albania. Heads of political parties, in order to fulfill the obligations of $30 \%$ of the candidates, were looking for 
young women in politics and civil society in the field or other areas less connected to politics.

One of the main purposes of the quote was to guarantee representation of both sexes in selected structures. However, Albania, since the beginning, was faced with the thought that what people wanted was the result of a prejudice, because in reality, there was no inequality between women and men. It was enough for women to compete and the mission was completed (Virtual Platform of the Albanian Women in Decision-Making, 2010)!

Although Albania has made progress in terms of the legal framework in terms of increasing the participation of women in politics and decision-making, the current situation shows that women are still underrepresented (Albania Institute for Social Innovation, 2013). There are some reasons for the low rate of representation of women in parliament, but the main one is the traditional culture and prejudice against women. On the other hand, the researcher thinks that there are a number of other obstacles that women must overcome.

Obstacles are the same everywhere in the world, for example, the lack of support from family, political parties, the difficulty of finding financial resources, or lack of confidence. When men aim a political career, it is easy. But when it comes to women, they must find a balance between professional career and life in general. In today's world, regarding women's representation in politics, there are two laws about the "iron lady", which clearly describe the situation of the penetration of women in the political elite:

Firstly, whatever the position or political privilege, there are always more men than women who compete for the position or privilege, even when women have them compete harder to grasp and secure it.

Secondly, the higher up in the hierarchy to positions, much less women will have them (Chapman, 1993).

In the Albanian reality, due to lack of a tradition of women participating in politics, communist heritage, frustration with policies, lack of space for socialization that provides paid employment outside the home and personal life social activity, due to poverty, structure traditional Albanian family that sees women as being humble to the will of the husband of the home, women are invisible and underrepresented. (Danaj, 2008)

Democracy is communication, collaboration, and relationship. In this particular role, obviously political voice communication is very interesting. Communication is a process of relationship and it is known that to communicate does not mean just to give a message, but to create a relationship where each has a role or even an image. People all are conscious of a mess in nowadays lecture and language facts heterogeneity. Language is not only a function of the speakers, but also it belongs to all communities. Language policy is the main tool used. Its policy depends on certain political interests and can be clear or unclear according to the authenticity of these policies. Range of political speech is diverse. Talking less and saying a lot, talking a lot and saying nothing; complicating phrases in order to hide the opinion; composing incomplete truths; and smiling while chewing hatred, all these are a range of expressive policy tools.

The style non infinito (unfinished style) is made as an evident feature, the speech of Albanian politicians who have returned to make evasive speech, the undefined. But political communication professionals know that the "abc" is political communication: A good politician should select words that says because it might take not only the meaning that speaker gives, but also the meaning of those who hear it (Fuga, 2005, p. 63).

The political situation in Albania recently has revealed exactly political criteria language, language which has been generally associated with the ideology of the left side or the right (though in some cases, there were dominated close political interests) conflict between the parties has been continuously present, and it is noticed that most is the lack of clarity of language. 
Since the June 2009 elections, the political language among deputies in parliament has been fierce. From both sides, epithets are used, which are to be used by people who do not deal with politics in their daily lives, they would have said some insulting words. Whosoever emerges in the public space to say his/her opinion should be willing to endure the remedy of words that could hurt (Fuga, 2011). Moreover, the public have dominated political communication with more emotional arguments, which have further hampered the political message transmission between the parties or not to say that it is not realistically be aired. Usually, these insults between people go there because they can easily bring physical altercation between individuals and so they can crash again.

But while it is seen that although the Albanian politics is "violent" to continue for women to approach, that there cannot be any way for beautiful and soft things, because now they have to make laws and decisions, because in the hands of this policy is the life of the state. It is clear that the environment (parliament) absolutely cannot be for beautiful things, especially when the situation aggravates and insults take place as it often happens in Albanian political environment .

If women in politics face the dilemma of "to feel like a woman or thinking like a man", for men, it is easier to overcome every time the rainbow (Buzi, 2009).

The political situation, in terms of communication, is almost in a kind of tension all the time and more during elections, whether parliamentary or local. This conclusion is based on a strong conviction that the communication referred to women in politics. Obliged to obey the orders of the chiefs (heads of parties), women politicians have changed the way of communication to the public. They no longer characterize the fragility or use soft tonality to absorb a little bit of conflict. Now, in the parliament or in the press conference rooms, strong phrases, the most serious charges, and harsher vocabulary are used by women. Especially when talking against each other, women cannot realize "smoothing" policy.

It is seen that ladies have spoken with no suitable policy to their rivals accusing them. All are convinced that those who are not publicly articulated or thought it was their true attitude, but a task that was given by the respective presidents, to throw mud on the opponent, and why not, to gain time television and newspaper pages.

It is not normal for Albanian society guided by an old antifeminist bias that comes from "the time of Freud", according to which "The destiny of the female is anatomic" (Tushi, 2008). In Albanian society, at all dimensions, it has prominent women and strong ones who would make a good turn to Albanian politics. Today, probably they are out, as there are many respected men. But in a historical perspective, women in this country have been able to walk the path of emancipation, so it is believed that our times would have to be brave to go that route (Zaimi, 2010).

\section{Topalli, a Politician Lady and Her Way of Communication}

For the first time in its history, the Albanian parliament finally elected a woman, Josefina Topalli, as its president (London, 2005). Topalli always thought of people such as men who hold responsibility, without any complex; women may hold that being a woman has neither helped nor hampered her work.

As not a few others, I have been wrong when I tried and suspected often that Topalli, unconsciously, was incomprehensible and unnecessary, even unwise, rides in politics, while it did not transmit as a female the role of a gentle woman, a wise politician, the "opponent of the opposition”, as promised, a Chief Assembly, with wisdom and kindness that manages to conceive Assembly, understanding, giving peace and good faith, to tame tempers well, as a "Mother Teresa” of policy. (Blushi, 2009) 
Obviously, work and tough fight on top of manly Assembly of Albania has become "more determined" against vandalism, banality, and words of hatred gestures. "I am not an 'iron woman', the information you gave me regarding the chair that I have, tells me that the path we have taken, it is difficult, but the only possible" (from the words of the Mrs. Topalli, voting session request for removal of her, November 13, 2006). From observation and comments, it appears that the institution of laws, often "make the law". The controversial language used in Parliament of Albania, a northern dialect pronounced and often outrageous and nervousness grade, remembered her reaction to the Assembly Hall, on July 22, 2008: "In contrast, we have seen more than once that she plays the role of a woman — man, often wild, stubborn, and intolerant. How is it possible, ask the Assembly men, who she said "chased me” whenever given the opportunity!”.

Mrs. Topalli was discussed during the public for loss of control in a fierce debate with Mr. Ball. She was also remembered for the sudden outbreak in 2005, a few days before the election, in a statement she made on TV Klan, three days before parliamentary elections on July 3, 2005 (Myftaraj, 2006).

Topalli politically knew to impose better than everyone, always hard and tough counter, of course not by chance, but deliberately which excluding the outer side of her, even with her flamethrowers vocabulary, vulgar and dialectical (Probably, in Albanian masculine military policy, it has a high importance!), she has made it possible, with an admirable tenacity targeted now giving herself a secure future for tomorrow. (Blushi, 2009)

If it would be considered the "forbidding" and reflected conversion of the examples above about Mrs. Topalli, it can be really argued that its presence in political activity could not become more feminine in her role, in a very masculine politic, such as Albania, in the fight for political survival. And in an interview with journalist Sokol Balla conducted for this study, he describes her profile as of the only lady in charge of a government in Albania, but its mission for gender equality (gender equality) is partially realized. "Today, Topalli is equivalent to a man at the head of the Parliament, but to get there, she had to give up her gender", Balla said.

Topalli, as well as other women in politics, knows that it is hard to have a future if the politician will behave differently: as a "housewife" crestfallen, like a good wife, wise and gentle, but they should create a parable of male/female in the party/politics. After only one such image can provide continuity and security guarantees for militants or anyone else and that tomorrow will be accepted as a worthy successor.

Another opinion, this time a female one, in a letter of 2006, has justified its change due to the extremely difficult challenge facing the "Complexion to be vigilant and to sleep, the defense turns in making goal at your door. Shame and anger that arouse a woman insults by men, killing the beauty and the beast awaken. An injured woman is a woman less, a necromancer more”, says in a written letter by Rudina Xhunga, for Topalli, at the time of the second motion of no confidence of the speaker (Xhunga, 2006).

Regarding the brutality and severity of its vocabulary opinions justifying that rudeness is absolutely an inevitable behavior in the hall of the Parliament, where the rules are often not respected by some deputies, who have become insults and swearing in working style. However, this does not justify the brutal gestures or words used by the only female high profile and indeed the political scene. There is value to this behavior that makes it many times, even without reason. Outgoing resembled a woman affected by severe vocabulary of men Albanian politicians. Now, it seems like a voice among them and provokes their voices be tougher. Despite the content of rude and dialect is pronounced, which makes it very difficult communication, the researcher thinks that it uses a dictionary somewhat rough after proper forms to establish authority in the district with which he 
works and interacts every day.

But to put a little powder on her portrait, in its image of a man and a woman, Mrs. Topalli emphasized looking across the country and the world, as an international class politician, as a woman with refinement, dedicated, dignified, determined, always elegant, with a perfect model of success and policy today! Looks quite different from the shape than the Parliament sessions!

When calculating the percentages of female participation in politics, the percentage of its masculinity should be taken in account. Because the predominant profile of an Albanian politician cannot possibly defeat manly features: severe behavior and communication, profile noticed in various media debates of both sexes (not talking about their behavior in the Parliament Hall).

Today, it seems that the trends are towards profiling women as domestic, romantic, cooks, even as politicians and government management. This Hegelian dualism seems to sculpt a new characterization in his hierarchy of modern women, masculing a female, who is physically a female and has a male ideologically (Konomi, 2010).

There has been a tendency for many years in the Balkan countries that had a masculine policy, therefore, has long been manly and women have brought and continue to bring their model, but also must be prepared to become part of real political view who will do this even when it is important encounters. In approaching the problem in a way, it is emotionally difficult to explain the situation that created polarization between "feminism in politics" and "masculine women". Perhaps, it will take time to understand the true implications of this bipolar symmetry.

Masculine is a person who rises in the morning and late in the day celebrate his personal ego gender while female masculinity would determine the wish to suppress the feminine side of a woman and to excite to her the manhood masculinity in a husband or a male. Feminism in politics, firstly, should be seen as main support of social gender equality and then as anticorruption policy articulation as well as those with social character, but we should beware against corruption of women, because their sanctity will be destroyed forever. Feminine masculinity has been long begun appearing in the media and politics. Not rarely we see a woman who speaks in political shape, stylistically as a male politician (Konomi, 2010).

Despite this reality, Albanian women should continue to be in politics considering that it will come a day when the laws of this country will be implemented. What has been seen in common, however, is that people all convert at one point, with speculation or political abuse of the women and their role and with the conviction that the Albanian political masculine dominance has no desire and willingness to open spaces for women, even in a near future. In a stricter way, it can be said that the debate is expected in certain situations, but that depends more on the individual person and how he/she expresses his/her communication.

\section{Conclusion}

Female gender has gradually evaluated over years, giving the world a better view of what can be done and how the world can be a better place with women that manage the political situations. People can grow and live in a world of solution done with knowledge from the past and from the ones who have the motherly spirit and humanity feelings to do what is the best. There is need for more time to achieve the purposes and to dislocate the mentality to not involve women in political cases, but the most important thing is that day by day women are getting considered in this area and gaining space to practice their profession and do politics. 


\section{References}

Blushi, K. (2009). Lady J. Albanian newspaper.

Buzi, D. (2009). Tears that must (not) be deposited in politics. Panorama.

Chafetz, J. (1999). Handbook of sociology of gender. New York, N.Y.: Kluwer Academic/Plenum Publishers.

Chapman, J. (1993). Politic, feminism and the reformation of gender. London, U.K.: Routledge.

Danaj, E. (2010). To master policy. Retrieved from http://saktivista.com/2010/09/ta-zoterosh-politiken/

Danaj, S. (2008). Invisible citizens in politics: Women in rural areas. Tirana: UET Press.

Edelman, M. (1985, Winter). Political language and political reality. Political Science \& Politics, 18(1), 10-19.

Fuga, A. (2005). Readings in communication. Time.

Fuga, A. (2009). How good political debate. Journal Standard.

Fuga, A. (2010). Where are you going political language. Retrieved from http://www.albeu.com/opinion/ artan-fuga/ku-po-shkongjuha-politike/25807/

Harrison, K., \& Boyd, T. (2003). Understanding ideas and movements. Manchester, U.K.: Manchester University Press.

Holmes, J., \& Meyerhoff, M. (2003). The handbook of language and gender. Blackwell.

Konomi, B. (2010). Maskilizimi of women in politics. Journal ENGLISH.

Londo, B. (2005). Finally Josefina. Journal Century.

Myftaraj, K. (2006). Topalli-Icons or Marie Antionette “DP”. Journal Today.

Sartori, G. (1998). Once again democracy. Tirana: Wisdom.

Tushi, J. (2008). Women, society and 8 March. Journal ENGLISH.

Virtual Platform of the Albanian Women in Decision-Making. (2010). Women's network "Equality in Decision-Making”. Retrieved from http://www.platformagjinore.al/eng/2012/04/08/womens-network-equality-in-decision-making-30-notaccomplished/\#

Xhunga, R. (2006). Ed and Josefina. Koha Jone.

Young, L. (2000). Feminists and party politics. UBC Press.

Zaimi, A. (2010). Women's perspective. Retrieved from http://saktivista.com/2010/09/grate-nen-perspektiven-e-\% E2\%80\%9Ckuotave-roze\%E2\%80\%9D/

Zekije, D. (2006). Modern and postmodern feminism. Skopje, Logos-A. 